\title{
Wykaz prac magisterskich napisanych na seminariach językoznawczych w Instytucie Filologii Polskiej UAM w roku akademickim 2010/2011
}

1. Joanna Adamczyk, Frazeologia $w$ prasie kobiecej (na przyktadzie „Świata Kobiety” $i$ „Przyjaciótki”) (prof. dr hab. Małgorzata Witaszek-Samborska ${ }^{1}$ ).

2. Aneta Ambros, Językowy obraz kobiety w ,Wysokich Obcasach" (prof. dr hab. Halina Zgółkowa).

3. Natalia Araszkiewicz, Celowe btędy językowe jako sposób budowania komizmu językowego oraz idiolektu postaci na przykładzie Violetty Kubasińskiej z serialu telewizyjnego „BrzydUla” (prof. dr hab. Andrzej Sieradzki).

4. Karolina B a nas zak, Agresja językowa $w$ nagtówkach prasowych (na przykładzie „Faktu”) (prof. dr hab. Małgorzata Witaszek-Samborska).

5. Urszula Bieniek, Wizerunek kobiety $w$ reklamie prasowej na przyktadzie „Cosmopolitan”, „Twojego Stylu”, „Playboya” $i$,CKM-u” (prof. dr hab. Eliza Grzelak).

1 W nawiasach umieszczono nazwiska promotorów prac.
6. Magdalena B rylows ka, Językowy obraz kobiety i mężczyzny we wspótczesnej prasie (prof. dr hab. Małgorzata Witaszek-Samborska).

7. Karolina Buczkowska, Słownictwo psychologiczne $w$ najnowszej polszczyźnie ogólnej (na podstawie „Uniwersalnego stownika języka polskiego" pod redakcja Stanistawa Dubisza) (prof. dr hab. Halina Zgółkowa).

8. Anna Budnik, Językowy stereotyp urzędnika $w$ świadomości społecznej (prof. dr hab. Halina Zgółkowa).

9. Anna Chodakowska-Człapska, Źródła metaforyki w gwarze uczniowskiej (prof. dr hab. Tadeusz Zgółka).

10. Karolina C i e m niak, Reklama prasowa jako przekaz polisemiotyczny adresowany do kobiet $i$ do mężczyzn (prof. dr hab. Eliza Grzelak).

11. Kamila Dembska, Wybrane techniki perswazyjne w reklamie prasowej (prof. dr hab. Andrzej Sieradzki).

12. Angelika Dębowiak, Etykieta językowa $w$ środowisku zawodowym (prof. dr hab. Eliza Grzelak). 
13. Monika Dębska, Uczniowska odmiana wspótczesnej polszczyzny (prof. dr hab. Halina Zgółkowa).

14. Marta Dominiak, Stownictwo wnętrzarskie $w$ prasie specjalistycznej (na podstawie „, Czterech Katów”) (prof. dr hab. Małgorzata Witaszek-Samborska).

15. Sebastian Drożyńs ki, Zapożyczenia angielskie $w$ stownictwie informatycznym obecnym $w$ polszczyźnie ogólnej (prof. dr hab. Małgorzata Witaszek-Samborska).

16. Monika Dudzińska, Stereotypy ptciowe $w$ świadomości językowej uczniów szkoty podstawowej (prof. dr hab. Eliza Grzelak).

17. Ewa Duszczak, Nazwy wtasne w cyklu „Opowiadań ćwierćabsurdalnych" Niżej Podpisanego (prof. dr hab. Irena Sarnowska-Giefing).

18. Natalia Fabiszewska, Skuteczność kampanii społecznej w Polsce na przykladzie reklam Fundacji Viva! (prof. dr hab. Eliza Grzelak).

19. Dorota Fila-Korbanek, Językowy obraz mężczyzny. Badania pragmalingwistyczne (prof. dr hab. Halina Zgółkowa).

20. Aleksandra Gałecka, Językowy ksztalt listów dzieci do Pana Boga (prof. dr hab. Halina Zgółkowa).

21. Joanna G ębicka, Ekspansja skrótowców $w$ prasie (na przyktadzie gazet "Polska Gtos Wielkopolski” $i$,,Przeglad Koniński”) (prof. dr hab. Anna Piotrowicz).

22. Beata Głuch, Stownictwo kosmetyczne na podstawie ,,Stownika języka polskiego" pod redakcja Mieczystawa Szymczaka (prof. dr hab. Małgorzata Witaszek-Samborska).

23. Małgorzata Golaczek, Rola ptci wświadomości językowej użytkowni- ków polszczyzny (prof. dr hab. Halina Zgółkowa).

24. Sylwia Goła, Toponimia. Nazwy miejscowe powiatu pilskiego (prof. dr hab. Halina Zgółkowa).

25. Michał Gondek, Wybrane aspekty języka komentatorów sportowych w ujęciu statystycznym (prof. dr hab. Andrzej Sieradzki).

26. Katarzyna Góra, Bariery komunikacyjne $w$ kazaniach (prof. dr hab. Eliza Grzelak).

27. Mateusz Gó ra, Komunikacja w matych zakładach pracy (prof. dr hab. Eliza Grzelak).

28. Joanna Gry ciu k, Zwiazki frazeologiczne z komponentem zwierzęcym w języku polskim i czeskim (prof. dr hab. Bogdan Walczak).

29. Małgorzata Grześk owiak, Innowacje frazeologiczne $w$ tygodniku „Polityka” (prof. dr hab. Małgorzata Witaszek-Samborska).

30. Barbara Hanuszkiewicz, Neologizmy dziecięce $w$ ujęciu pragmalingwistycznym (prof. dr hab. Halina Zgółkowa).

31. Hanna Horbacz, Stopień znajomości słownictwa komputerowego przez przedszkolaki i młodzież wczesnoszkolna (prof. dr hab. Małgorzata Witaszek-Samborska).

32. Agnieszka Ilnicka, Slogan reklamowy jako forma komunikacji marketingowej w Internecie (prof. dr hab. Eliza Grzelak).

33. Piotr Jakubowski, Komunikacja niewerbalna jako źródto odczytywania interakcji międzyludzkich (prof. dr hab. Tadeusz Zgółka).

34. Anita Jankowska, Świadomość normy językowej wśród użytkowników polszczyzny (prof. dr hab. Anna Piotrowicz). 
35. Anna J a now i c z, Polszczyzna konsumpcyjna $w$ powieści Lauren Weisberger „Diabet ubiera się u Prady” $w$ thumaczeniu Hanny Szajowskiej (prof. dr hab. Anna Piotrowicz).

36. Anna Jarmuż, Perswazja językowa $w$ kontaktach sprzedawca-klient (prof. dr hab. Halina Zgółkowa).

37. Aleksandra Jędrzejczak, Błędy językowe osób niemieckojęzycznych uczacych się języka polskiego (prof. $\mathrm{dr}$ hab. Irena Sarnowska-Giefing).

38. Sandra Kaczmarek, Erotyczny wizerunek kobiety $w$ reklamach telewizyjnych (prof. dr hab. Tadeusz Zgółka).

39. Michał Kadłubowicz, Polskie stownictwo kolejowe (prof. dr hab. Andrzej Sieradzki).

40. Mateusz Kaptur, Akronimy angloamerykańskie $w$ polskim języku internetowym (prof. dr hab. Andrzej Sieradzki).

41. Marta Karmolińska, Wartościowanie $w$ literaturze dla dziewczat. Wartości dobra $i$ zła $w$ literaturze $z$ lat trzydziestych, piećdziesiatych $i$ wspótczesnej (prof. dr hab. Alicja Pihan-Kijasowa).

42. Anna Karolewska, Charakterystyka stownictwa ekonomicznego polszczyzny drugiej połowy XX wieku (prof. dr hab. Małgorzata Witaszek-Samborska).

43. Aneta Koladyńska, Słownictwo rolnicze we wspótczesnej polszczyźnie (na podstawie ,Uniwersalnego stownika języka polskiego" pod redakcja Stanisława Dubisza) (prof. dr hab. Małgorzata Witaszek-Samborska).

44. Anna Kordus, Stownictwo sportowe (na przyktadzie żargonu i terminologii specjalistycznej lekkoatletów) (prof. dr hab. Andrzej Sieradzki).
45. Anna Korzeniows ka, Tytuly urzędowe $i$ grzecznościowe $w$,Pamiatkach Soplicy” Henryka Rzewuskiego (prof. dr hab. Andrzej Sieradzki).

46. Agnieszka Kotowicz, Wulgaryzacja języka w ksiażce Ewy Egejskiej „Czarodziejki.com” (prof. dr hab. Małgorzata Witaszek-Samborska).

47. Katarzyna Kowalska, Leksyka młodzieżowa (wybrane problemy) (prof. dr hab. Andrzej Sieradzki).

48. Natalia Kozak, Językowy obraz księdza w tygodniku ,Fakty i Mity” (prof. dr hab. Andrzej Sieradzki).

49. Weronika Kozakiewicz, Semantyka barw $w$ powieściach Olgi Tokarczuk (prof. dr hab. Małgorzata Witaszek-Samborska).

50. Szymon Kozłowski, Mieć czy być? Rzeczywistość w tekstach zespotu ,Myslovitz” (prof. dr hab. Tadeusz Zgółka).

51. Agnieszka Krenc, „Always Coca-Cola" - synteza humanistycznych rozważań nad sloganem reklamowym (prof. dr hab. Eliza Grzelak).

52. Dagmara Kubiaczyk, Stownictwo harcerskie we współczesnej polszczyźnie (prof. dr hab. Małgorzata Witaszek-Samborska).

53. Joanna Kubiak, System mikrotoponimiczny Tatr Wysokich. Struktura motywacja - funkcja (prof. dr hab. Irena Sarnowska-Giefing).

54. Anna Ku siak, Palikotyzacja-czyli o politycznym idiolekcie oraz idiostylu Janusza Palikota (prof. dr hab. Halina Zgółkowa).

55. Małgorzata Lachowicz, Podobieństwa i różnice $w$ przekładzie polskich i niemieckich idiomów, powiedzeń $i$ przystów, nawiazujacych do nazw zwierzat (prof. dr hab. Halina Zgółkowa). 
56. Natalia L e h m a n n, Język perswazji w polskiej reklamie prasowej na podstawie czasopism kobiecych i specjalistycznych (prof. dr hab. Małgorzata Witaszek-Samborska).

57. Oskar L e p c zyń sk i, Polskie zwiazki frazeologiczne z nazwami zwierzat w nauczaniu obcokrajowców. Zjawisko ekwiwalencji w obszarze frazeologii polskiej i hiszpańskiej (prof. dr hab. Irena Sarnowska-Giefing).

58. Joanna Łazinka, Świadomość językowa Polonii amerykańskiej (prof. dr hab. Małgorzata Witaszek-Samborska).

59. Anna Łuczak, Zapożyczenia $w$,Praktycznym stowniku współczesnej polszczyzny" pod redakcja Haliny Zgółkowej (A-J) (prof. dr hab. Halina Zgółkowa).

60. Tomasz Maik, Modele metaforycz$n e w$ prasie sportowej $w$ ujęciu kognitywnym (na przykładzie „Przegladu Sportowego") (prof. dr hab. Małgorzata Witaszek-Samborska).

61. Agata Majchrzak, Tomasz Sianecki jak autorytet językowy (prof. dr hab. Halina Zgółkowa).

62. Anna Majorczyk, Nazwy barw $w$,Komediantce” $i w$,Fermentach” Wtadystawa Stanistawa Reymonta (prof. dr hab. Maria Borejszo).

63. Małgorzata Makuch, Językowy ksztalt życzeń walentynkowych (prof. $\mathrm{dr}$ hab. Maria Borejszo).

64. Edyta M a le p s z a, Językowy stereotyp urzędnika administracji państwowej $i$ samorzadowej (prof. dr hab. Halina Zgółkowa).

65. Aleksandra Małecka, Kompetencja $w$ zakresie języka polskiego Polaków w Szwecji (prof. dr hab. Irena Sarnowska-Giefing).

66. Alicja Mań k o w s k a, Językowy obraz Polaka w podręcznikach do na- uczania języka polskiego jako obcego z serii ,Hurra!!! Po polsku” (prof. dr hab. Andrzej Sieradzki).

67. Natalia Michalak, Gwara uczniowska jako środowiskowa odmiana języ$k a$ (prof. dr hab. Halina Zgółkowa).

68. Sylwia Michalak, Jezzykowo-kulturowy wizerunek odbiorcy celowego kreowany w prasie kobiecej (prof. $\mathrm{dr}$ hab. Eliza Grzelak).

69. Tomasz Mioduszewski, Problematyka języka w nauczaniu dzieci gluchych. Polski język migowy (prof. dr hab. Małgorzata Witaszek-Samborska).

70. Marika Naskręt, Wokót wizażanek. Jezzyk kobiet na forum internetowym Wizaz.pl (prof. dr hab. Irena Sarnowska-Giefing).

71. Daria Obst, Stownictwo pola tematycznego Wierzenia i Przesqdy w gwarze okolic Grybowa (prof. dr hab. Jerzy Sierociuk).

72. Marta Owsianna, Stownictwo sportowe z wyróżnieniem leksyki narciarskiej w ksiażce ,Bieg życia Justyny" (prof. dr hab. Halina Zgółkowa).

73. Angelika P ała s z, Profesjolekt jako narzędzie komunikacji werbalnejpracowników call centre linii lotniczych (prof. dr hab. Halina Zgółkowa).

74. Izabela $\mathrm{Paw}$ a k, Kreowanie wizerunku szkót wyższych (prof. dr hab. Eliza Grzelak).

75. Edyta Piasek, Frazeologia $w$ powieści Wiesława Myśliwskiego ,, Traktat o tuskaniu fasoli" (prof. dr hab. Małgorzata Witaszek-Samborska).

76. Anna P i kuła, Imiona mieszkańców gminy Niegowa z lat 1915-2011 (prof. dr hab. Irena Sarnowska-Giefing).

77. Agnieszka Portka, „O dobrym $i$ zlym patriotyzmie", czyli o wartościowaniu w prasie na podstawie katastrofy smoleńskiej $i$ wydarzeń z nia 
zwiqzanych (prof. dr hab. Halina Zgółkowa).

78. Mariola Przybyłek-Lis, Przysłowia $i$ wyrażenia przystowiowe w wybranych komediach Aleksandra Fredry (prof. dr hab. Andrzej Sieradzki).

79. Urszula Rataj, Komunikacja za pomoca komentarzy elektronicznych na przykładzie portalu internetowego Gazeta.pl (prof. dr hab. Eliza Grzelak).

80. Emilia Romanowska, Nazwiska Żydów Poznania z lat 1935-1940 (prof. dr hab. Irena Sarnowska-Giefing).

81. Yana Rutkovskaya, Wptyw bilingwizmu na polszczyznę młodzieży pochodzqcej z krajów obszaru postradzieckiego (prof. dr hab. Tadeusz Zgółka).

82. Judyta Rykowska, „Sprzatnać śmieciucha", czyli językowa specyfika bloga pamiętnikarskiego (prof. $\mathrm{dr}$ hab. Halina Zgółkowa).

83. Izolda Sakhnevich, Rozumienie wyrazów potocznych przez Polaków mieszkajacych $w$ Kazachstanie (prof. dr hab. Andrzej Sieradzki).

84. Izabela Sałacka, Charakterystyka reklam $w$ czasopismach ekskluzywnych (prof. dr hab. Tadeusz Zgółka).

85. Joanna Sikora, Jezykowy obraz Izabeli Łęckiej w „Lalce” Bolesława Prusa (prof. dr hab. Alicja Pihan-Kijasowa).

86. Anna Skowron, Podstawowa terminologia językoznawcza $w$ języku polskim i serbskim/chorwackim $w$ ujęciu porównawczym (prof. dr hab. Stanisław Mikołajczak).

87. Michał Skowroński, Językowa autorefleksja nad pytaniami $w$ wywiadach Krzysztofa Skowrońskiego (prof. dr hab. Halina Zgółkowa).
88. Honorata Sławecka, Świat zwierzęcy we frazeologii polskiej. Ssaki dzikie i udomowione (prof. dr hab. Małgorzata Witaszek-Samborska).

89. Katarzyna Stawna, Nazwy barw w czasopismach dla kobiet i mężczyzn (prof. dr hab. Małgorzata Witaszek-Samborska).

90. Agnieszka Szpylma, Stylizacja językowa w , Galeonach wojny” Jacka Komudy (prof. dr hab. Andrzej Sieradzki).

91. Kinga Szymankiewicz, $O$ komunikacji w szkole podstawowej. Relacje nauczyciele-uczniowe (prof. $\mathrm{dr}$ hab. Eliza Grzelak).

92. Anna Szy mańsk a, Czesko-polskie pułapki interferencyjne. $\mathrm{Na}$ podstawie analizy błędów językowych studentów uczacych się języka polskiego na Uniwersytecie Palackiego w Ołomuńcu (prof. dr hab. Irena Sarnowska-Giefing).

93. Radosław Śledziński，Pragmalingwistyczne aspekty wywiadu i rozmowy na przykładzie telewizji WTK (prof. dr hab. Halina Zgółkowa).

94. Wioletta Wachel, Stownictwo potoczne $w$ wypowiedziach polityków (prof. dr hab. Anna Piotrowicz).

95. Paweł Wawrzy now ic z, Reportaze Mariusza Szczygła w ujęciu pragmalingwistycznym (prof. dr hab. Halina Zgółkowa).

96. Emilia Weihs, Seks $w$ wielkim (i małym) mieście, czyli świadomość językowa użytkowników języka na terenie Poznania i Nowego Tomyśla $w$ zakresie stownictwa zwiazanego z ludzka seksualnościq (prof. dr hab. Tadeusz Zgółka).

97. Marta Widzińska, Polskie słownictwo botaniczne - oficjalne $i$ potoczne (wybrane zagadnienia) (prof. dr hab. Andrzej Sieradzki). 
98. Irmina W i e c zor e k, Leksyka, ,politycznie (nie)poprawna" w świadomości współczesnych Polaków (prof. dr hab. Halina Zgółkowa).

99. Magdalena Wo c i or, Młodzieżowy język erotyczny (prof. dr hab. Eliza Grzelak).

100. Kinga Wolk o, Feminizm i seksizm w języku mediów (prof. dr hab. Tadeusz Zgółka).

101. Agnieszka Zalewska, Metody autoprezentacji w wybranych sytuacjach komunikacyjnych (prof. $\mathrm{dr}$ hab. Eliza Grzelak).

102. Adriana Z i m o c h, Motta do nekrologów prasowych $i$ inskrypcji nagrobnych (na wybranym materiale $z$ lat 2008-2009) (prof. dr hab. Maria Borejszo).

103. Magdalena Zi ółk ow s ka, Wspótczesne stownictwo sportowe (na przyktadzie tenisa ziemnego) (prof. dr hab. Małgorzata Witaszek-Samborska).

104. Anna Zys-Ruszkowska, Leksykalne i pragmalingwistyczne uzasadnienia nazw oceny negatywnej uzywanych $w$ gwarze uczniowskiej (prof. dr hab. Tadeusz Zgółka).

105. Paulina Żupaniec, Pytania $w w y$ wiadach z cyklu ,, Mistrz i Matgorzata" Matgorzaty Domagalik w miesięczniku ,Pani" (prof. dr hab. Halina Zgółkowa).

106. Izabela Żurowska, Prowokacja językowa $w$ audycji radiowej ,Woobie Doobie" (prof. dr hab. Halina Zgółkowa).

Sporządziła

Agnieszka Krygier-Łaczkowska 